\title{
Medical Diagnoses for Sale or for Political Reasons: We are all Victims
}

\author{
OMOBOLA AWOSIKA OYELEYE, Ed D, J.D., M.Ed, MSN, RN-BC, CNE, CHSE, CPHQ \\ omobola.a.oyeleye@uth.tmc.edu \\ Cizik Shool of Nursing, Houston, Texas, U.S.A.
}

Keywords: doctor's notes, Americans with Disabilities Act, Learning Disabilities, ethics, altruism, psychologists, nurses, dentists, fake medical records, college admissions, teacher walk-out, Wisconsin.

Abstract: The article discusses the implications of the actions of health care professionals who engage in unethical conduct for altruistic purposes or for pecuniary gain. It analyzes the highly publicized news story where parents allegedly paid a lot of money to get their children admitted to colleges, including engaging the services of psychologists who created fake diagnoses of learning disabilities. It explores earlier unethical acts by healthcare professionals like physicians in Wisconsin who wrote work excuse notes for Wisconsin teachers, without any physician/patient relationship or assessments, and dentists and nurses who violated their professional ethical principles. Also discussed, is the impact of such acts on the respective professions and the potential impact on unseen victims like individuals with disabilities. The universality of the impact and the need for communal vigilance are highlighted.

\section{INTRODUCTION}

In February 2011, Wisconsin teachers staged a walk-out protesting their governor's plan to, among other things, require a higher contribution from public workers towards their insurance and pension. This would have resulted in a pay cut for many, as much as 7 percent, in some cases. ${ }^{1}$ On one of the days when the teachers were gathered at the Wisconsin Capitol, some physicians appeared on the scene, pads in hand, and wrote excuse notes openly for anyone who asked for it. Their actions were decried and condemned by many, including other physicians. ${ }^{2}$

Eight years later, in the early part of 2019, news broke that some parents had been paying huge sums of money to an individual who then paid university officials to help secure admissions for students through illegal acts. In some cases, the students' applications touted their skill and ability in one sport or the other. In the cases that are of direct relationship to this discussion, psychologists were hired, allegedly to provide the students with learning disabilities diagnoses so that they could take advantage of testing accommodations provided under the Americans with Disabilities Act. ${ }^{3}$

*Address correspondence to: Omobola Awosika Oyeleye, Ed D, J.D., M.Ed, MSN, RN-BC, CNE, CHSE, CPHQ. Cizik Shool of Nursing, 6901 Bertner Avenue, Room743, Houston, TX 77030, U.S.A. E-mail: omobola.a.oyeleye@uth.tmc.edu

+To cite this article: Omobola A. Oyeleye "Medical Diagnoses for Sale or for Political Reasons: We are all Victims, "The Journal of Healthcare Ethics \& Administration 5, no. 1 (Fall/Winter 2019): 1-6, https://doi.org/10.22461/jhea.1.71620

This work is brought to you for free and open access by the Institute of Clinical Bioethics (ICB) at Saint Joseph's University, Philadelphia, PA, U.S.A. It has been accepted for inclusion in The Journal of Healthcare Ethics \& Administration by the editorial board and an authorized administrator of the JHEA. For more information, please contact support@jheaonline.org

\footnotetext{
${ }^{1}$ Davey, Monica, and Stephen Greenhouse. 2011. "Public Workers in Wisconsin Protest Plan to Cut Benefits." The New York Times, February 16, 2011. https://www.nytimes.com/2011/02/17/us/17wisconsin.html

${ }^{2}$ Vox, Ford. 2011a. "Wisconsin's Real Doctors and Their Fake Sick Notes for Protesters." The Atlantic. February 21, 2011. https://www.theatlantic.com/national/archive/2011/02/wisconsins-real-doctors-and-their-fake-sick-notes-for-protesters/71500/

${ }^{3}$ Student Extra Time on Test - The Boston Globe." BostonGlobe.Com. March 22, 2019. https://www.bostonglobe.com/metro/2019/03/22/stupidadvice-from-admitted-mastermind-college-admissions-scandal-get-student-extra-time-test/WH66mfnndUEHvuBzfOvfNL/story.html
} 


\section{THE JOURNAL OF HEALTHCARE ETHICS \& ADMINISTRATION}

Vol. 5 | No. 1 (Fall/Winter 2019)

\section{THE AMERICANS WITH DISABILITIES ACT}

The Americans with Disabilities Act of 1990, and amended in 2008, was the premier civil rights legislation that sought to provide a level playing field for people with disabilities in employment, public accommodations, and state and local government programs. ${ }^{4}$ Consisting of five Titles, two of the Titles contain provisions that specifically require testing entities to provide reasonable accommodation to individuals with disabilities such that they are able to demonstrate their knowledge of and competence in the subject matter. ${ }^{5}$ Some of the reasonable accommodations possible under the Americans with Disabilities Act as Amended (ADAAA) include extra time, distraction-free testing space, and other barrier removal accommodations. The ADAAA was not designed to give an unfair advantage to individuals with disabilities. It was to level the playing field. The students in the college scandal abused the law, and professionals helped them to do it, for about four or five thousand dollars. ${ }^{6}$

\section{THE ETHICAL OBLIGATIONS HEALTH-RELATED PROFESSIONS}

Creating fake records is not an entirely new phenomenon, nor is it limited to physicians and psychologists. There are many instances in which members of other health professions have created fake medical records and entries. For example, a nurse documented more than fifty entries of clinical tasks that did not occur, ${ }^{7}$ and a dentist created dental records for services he had not provided, and billed Medicaid for them ${ }^{8}$ One difference between the case of the dentist and the nurse mentioned above is that the physicians who wrote the fake doctors' notes in Wisconsin were not criminally charged, and the psychologists have not been charged with a crime at the time of this writing.

Psychologists, as well as other health care professionals operate under professional standards and a code of ethics that require, at a minimum, a complete and accurate record of their patient care activities, and under a code of ethics that prohibits falsifying or creating inaccurate records. ${ }^{9}$ Nurses, ${ }^{10}$ physicians, ${ }^{11}$ and dentists, ${ }^{12}$ are required to practice under ethical provisions that demand integrity, honesty, and responsibility.

In many instances, creating false medical records or doctor's notes would attract legal as well as professional consequences. As many as twenty of the Wisconsin physicians were disciplined by their employer, the University of WisconsinMadison, ${ }^{13}$ and some were disciplined by Wisconsin's Medical Examining Board. ${ }_{-}^{14}$ The investigation into the college admission

\footnotetext{
${ }^{4}$ Americans with Disabilities Act of 1990, As Amended with ADA Amendments Act of 2008. 2013. Ada.Gov. 2013. https://www.ada.gov/pubs/adastatute08.htm

${ }^{5}$ United States Department of Justice Civil Rights Division Disability Rights Section. 2014. "ADA Requirements: Testing Accommodations." Ada.Gov. 2014. https://www.ada.gov/regs2014/testing_accommodations.html

${ }^{6}$ Levenson, Michael. 2019. "'Be Stupid' -- Advice from the Admitted Mastermind of the College Admissions Scandal to Get Student Extra Time on Test - The Boston Globe." BostonGlobe.Com. March 22, 2019. https://www.bostonglobe.com/metro/2019/03/22/stupid-advice-fromadmitted-mastermind-college-admissions-scandal-get-student-extra-time-test/WH66mfnndUEHvuBzfOvfNL/story.html

${ }^{7}$ Beshah v. Commonwealth, 725 S.E. 2d 144 (2012), 144.

${ }^{8}$ The New York Times. 2012. "New Jersey Dentist Is Accused of Medicaid Fraud," March 9, 2012. https://www.nytimes.com/2012/03/09/nyregion/new-jersey-dentist-is-accused-of-medicaidfraud.html?mtrref=www.bing.com\&mtrref=www.nytimes.com\&gwh=C55E9BDEF2A8F08FA005999D4772552B\&gwt=pay\&assetType=REGIWALL

${ }^{9}$ American Psychological Association. 2017. "Ethical Principles of Psychologists and Code of Conduct." https://www.apa.org/ethics/code/ethics-code-2017.pdf

${ }^{10}$ American Nurses Association, "Code of Ethics for Nurses," ANA, 2015, https://www.nursingworld.org/practice-policy/nursingexcellence/ethics/code-of-ethics-for-nurses/

${ }^{11}$ American Medical Association. 2019. "AMA Code of Medical Ethics AMA Principles of Medical Ethics *." https://www.amaassn.org/sites/ama assn.org/files/corp/media-browser/principles-of-medical-ethics.pdf

${ }^{12}$ American Dental Association. n.d. "ADA Principles of Ethics and Code of Professional Conduct." Ada.Org. Accessed September $28,2019$. https://www.ada.org/en/about-the-ada/principles-of-ethics-code-of-professional-conduct

13 NBC15. 2012. "UPDATE: Doctor Notes Provided for Protesting Teachers." Nbc15.Com. 2012. https://www.nbc15.com/home/headlines/Doctor_Notes_Provided_For_Protesting_Teachers_116544948.html
} 


\section{THE JOURNAL OF HEALTHCARE ETHICS \& ADMINISTRATION}

Vol. 5 | No. 1 (Fall/Winter 2019)

scandal is ongoing, and none of the psychologists have been named or charged with a crime at this time, and there is no guarantee that they will be. Hence the need for health-related professions to vigorously police themselves on such matters.

\section{CONSEQUENCES AND IMPACT FALSIFYING MEDICAL RECORDS}

Each of these types of news comes with residual effects on unintended victims, and no degree of sanctions on the erring professionals will make up for those residual effects. There are consequences to members of the public and to the health care professions collectively. A consequence that relates to this discussion is the potential gradual undermining of the professions, specifically the undermining of the veracity of medical records. ${ }^{15}$

Medical records are the bedrock of patient care and patient safety. They guarantee safe continuity of care and impose confidence in the treatment plans for future care by other health care professionals. ${ }^{16}$

The physicians' action in writing the fake notes yielded immediate consequences in that the school district rejected the notes brought in by the teachers, asking that the physicians rescind the notes. This is a clear demonstration of contempt for the professional standing of the physicians who wrote the notes. ${ }^{17}$

This was aptly captured in the sentiments of Dr. Derse, Director of the Center for Bioethics and Medical Humanities at the Medical College of Wisconsin, where the physicians were employed, "When all's said and done, it's really the profession of medicine that has the black eye in this case." ${ }^{18}$

A serious potential consequence of the psychologists' actions is its impact on the welfare and opportunities for individuals with disabilities. That act of deception will likely create new barriers in that the proof of their disabilities written by professionals will be mistrusted, and testing agencies will raise their evidentiary requirements for reasonable accommodations requests. ${ }^{19}$ This goes against the very reason for the creation of the Americans with Disabilities Act, which was to remove barriers and allow individuals with disabilities to participate fully as members of their communities. $\underline{20}$

The far-reaching consequences are not just about their standing as professionals. Another important and saddening consequence of perpetrating such falsehood is that future diagnoses will lose believability. For example, in determining who qualifies for reasonable accommodations for testing, the Americans with Disabilities Act as Amended (ADAAA) gives priority to reports prepared by qualified professionals, stating that "testing entity should generally accept such documentation and provide the recommended testing accommodation without further inquiry." ${ }^{21}$ Future recommendations may no longer enjoy the same authority that the ADAAA intended.

\footnotetext{
${ }^{14}$ Marley, Patrick. 2012. “Eleven Doctors Disciplined for Handing out Fake Sick Notes during Protest." Jsonline.Com. 2012. http://archive.jsonline.com/news/statepolitics/eleven-doctors-disciplined-for-handing-out-fake-sick-notes-during-protest-s2818ua183427451.html

${ }^{15}$ Vox, "Wisconsin's Real Doctors"

${ }^{16}$ Brown, L. 2015. “Inadequate Record Keeping by Dental Practitioners." Australian Dental Journal 60 (4): $497-502$. https://doi.org/10.1111/adj.12258

17 DeFour, Matthew. 2011. "Madison Teachers given until April 15 to Rescind Fake Doctors' Notes." Madison.Com. July 5, 2011. https://madison.com/wsj/news/local/education/madison-teachers-given-until-april-to-rescind-fake-doctors-notes/article_d114b69c-5657-11e095d8-001cc4c03286.html

${ }^{18}$ Vox, "Wisconsin's Real Doctors"

19 Levinson, "Be Stupid"

20 United States Department of Justice Civil Rights Division Disability Rights Section. n.d. "Introduction to the ADA." Ada.Gov. Accessed September 28, 2019. https://www.ada.gov/ada_intro.htm

${ }^{21}$ United States Department of Justice Civil Rights Division Disability Rights Section. 2014. "ADA Requirements: Testing Accommodations." Ada.Gov. 2014. https://www.ada.gov/regs2014/testing_accommodations.html
} 


\section{ALTRUISTIC VERSUS PECUNIARY REASONS: SHOULD THERE BE A DISTINCTION?}

Members of the health professions often condemn colleagues who engage in such unethical conduct and often call for some form of repercussions, such as sanctions, fines, and criminal prosecution. When the offenders receive a reprimand or punishment, it sometimes assuages their outrage and that of the public. That is until the next time a similar story hits the airwaves and the news cycle.

Within the rounds of condemnation surrounding the Wisconsin physicians, an argument emerged that the physicians' act was justifiable since they were engaging in advocacy, a worthy cause that should otherwise be lauded. The main argument was that the news media is unable to separate the individuals from their profession as physicians. ${ }^{22}$ Therefore, physicians should be more careful next time and not be so public about similar activities. Is it right to require the news media to separate the physicians' actions from their profession even though they appeared at the protest rallies as physicians and acted as physicians?

This is a question we must ask: Is the act of falsifying medical records or doctor's notes a neutral act that may be ethical or otherwise, based solely on whether it is public or private act? Do these acts not erode the professional standing of the actor, whether it is in the presence of one person, or when it has gone viral? Does the end justify the means?

In the case of the psychologists and the alleged fake disabilities diagnoses, their actions were private, far from public protest rallies. Yet, they received strong condemnation. Their actions were described as egregious and not representative of the profession. ${ }^{23}$ There is no doubt that such an act diminished their profession, even though it occurred in private, and they probably expected it to remain private. The act itself diminished their profession long before the issue became public. As we now know, the consequences are far reaching.

\section{THE NEED FOR REDUCED TOLERANCE FOR COLLEAGUES WHO CREATE FAKE RECORDS}

A continued and highly publicized violation of professional practice standards and ethical principles will likely promote distrust of the veracity of records created by healthcare-related professionals. The more the publicity that surrounds these violations, the greater the chances that the public and payers will look askance at medical records, and resist taking them seriously. In today's highly socialized media, that will likely happen. In addition, health care professionals may increasingly doubt the accuracy of medical records and notes created by their colleagues. That will likely have deleterious consequences on patient care. It will likely increase the cost of healthcare because individual providers will seek to run their own tests.

Health care professionals owe it to themselves and their professions to comply with their profession's codes of ethics by ensuring that patient records are accurate and complete. The respective codes of ethics also require that physicians report colleagues who engage in fraudulent or deceptive practices, ${ }^{24}$ that nurses maintain the integrity of the profession, ${ }^{25}$ and that psychologists first personally address perceived ethical violations with the offending colleague, and then report to the state or national committees on professional ethics, to state licensing boards, or to the appropriate institutional authorities," if the personal approach fails. $\frac{26}{6}$ Clearly, there is an obligation to do more than just shake our collective heads.

Healthcare professionals must not view these ethical violations as isolated incidences, but as an insidious erosion of the profession's collective integrity. It is not just about "them," the offenders. It is about all of us. Every time we read about a "fake

\footnotetext{
${ }^{22}$ Vox, Ford. 2011. "The Risks of Professional Protest." Virtual Mentor 13 (10): 726-30. https://doi.org/10.1001/virtualmentor.2011.13.10.oped11110

${ }^{23}$ Levenson, "Be Stupid"

${ }^{24}$ American Medical Association. 2019. "AMA Code of Medical Ethics AMA Principles of Medical Ethics *." https://www.ama-assn.org/sites/amaassn.org/files/corp/media-browser/principles-of-medical-ethics.pdf

${ }^{25}$ American Nurses Association. 2015. “Code of Ethics for Nurses.” ANA. 2015. https://www.nursingworld.org/practice-policy/nursingexcellence/ethics/code-of-ethics-for-nurses/

${ }^{26}$ American Psychological Association. 2017. “Ethical Principles of Psychologists and Code of Conduct.” https://www.apa.org/ethics/code/ethicscode-2017.pdf
} 
doctor's note" it should never be by a doctor. It should be a note by a "fake doctor," rather than a fake note written by a doctor. And every time we read a medical report, we should never have to doubt that it represents the true state of the patient's health.

For health care professionals who choose to violate their professional ethical standards, either for personal pecuniary purposes or for altruistic reasons, they must be mindful that neither act is victimless. There are always victims who are not in the room or at the protest rally, but who will nevertheless bear the consequences of the actions perpetrated by those who take professional oaths to do no harm. The victims are you and me.

\section{BIBLIOGRAPHY}

American Dental Association. n.d. "ADA Principles of Ethics and Code of Professional Conduct." Ada.Org. Accessed September 28, 2019. https://www.ada.org/en/about-the-ada/principles-of-ethics-code-ofprofessional-conduct

American Medical Association. 2019. "AMA Code of Medical Ethics AMA Principles of Medical Ethics *." https://www.ama-assn.org/sites/ama-assn.org/files/corp/media-browser/principles-of-medical-ethics.pdf

American Nurses Association. 2015. "Code of Ethics for Nurses." ANA. 2015. https://www.nursingworld.org/practice-policy/nursing-excellence/ethics/code-of-ethics-for-nurses/

American Psychological Association. 2017. "Ethical Principles of Psychologists and Code of Conduct." https://www.apa.org/ethics/code/ethics-code-2017.pdf

Americans with Disabilities Act of 1990, As Amended with ADA Amendments Act of 2008. 2013. Ada.Gov. 2013. https://www.ada.gov/pubs/adastatute08.htm

Beshah v. Commonwealth, 725 S.E. 2 d 144 (2012), 144.

Brenan, Megan. 2018. "Nurses Again Outpace Other Professions for Honesty, Ethics." Gallup.Com. December 20, 2018. https://news.gallup.com/poll/245597/nurses-again-outpace-professions-honesty-ethics.aspx

Brown, L. 2015. "Inadequate Record Keeping by Dental Practitioners." Australian Dental Journal 60 (4): 497502. https://doi.org/10.1111/adj.12258

Davey, Monica, and Stephen Greenhouse. 2011. "Public Workers in Wisconsin Protest Plan to Cut Benefits." The New York Times, February 16, 2011. https://www.nytimes.com/2011/02/17/us/17wisconsin.html

DeFour, Matthew. 2011. "Madison Teachers given until April 15 to Rescind Fake Doctors' Notes." Madison.Com. July 5, 2011. https://madison.com/wsj/news/local/education/madison-teachers-given-untilapril-to-rescind-fake-doctors-notes/article_d114b69c-5657-11e0-95d8-001cc4c03286.html

Levenson, Michael. 2019. "'Be Stupid' -- Advice from the Admitted Mastermind of the College Admissions Scandal to Get Student Extra Time on Test - The Boston Globe." BostonGlobe.Com. March 22, 2019. https://www.bostonglobe.com/metro/2019/03/22/stupid-advice-from-admitted-mastermind-collegeadmissions-scandal-get-student-extra-time-test/WH66mfnndUEHvuBzfOvfNL/story.html

Marley, Patrick. 2012. "Eleven Doctors Disciplined for Handing out Fake Sick Notes during Protest." Jsonline.Com. 2012. http://archive.jsonline.com/news/statepolitics/eleven-doctors-disciplined-for-handingout-fake-sick-notes-during-protest-s2818ua-183427451.html

NBC15. 2012. "UPDATE: Doctor Notes Provided for Protesting Teachers." Nbc15.Com. 2012. https://www.nbc15.com/home/headlines/Doctor_Notes_Provided_For_Protesting_Teachers_116544948.ht $\mathrm{ml}$

The New York Times. 2012. "New Jersey Dentist Is Accused of Medicaid Fraud," March 9, 2012. https://www.nytimes.com/2012/03/09/nyregion/new-jersey-dentist-is-accused-of-medicaid-

fraud.html?mtrref=www.bing.com\&mtrref=www.nytimes.com\&gwh=C55E9BDEF2A8F08FA005999D 4772552 B\&gwt=pay\&assetType=REGIWALL

United States Department of Justice Civil Rights Division Disability Rights Section. n.d. "Introduction to the ADA." Ada.Gov. Accessed September 28, 2019. https://www.ada.gov/ada_intro.htm

United States Department of Justice Civil Rights Division Disability Rights Section. 2014. "ADA Requirements: $\quad$ Testing Accommodations." 2014. https://www.ada.gov/regs2014/testing_accommodations.html

Vox, Ford. 2011. "The Risks of Professional Protest." Virtual Mentor 13 (10): 726-30. https://doi.org/10.1001/virtualmentor.2011.13.10.oped1-1110 


\section{THE JOURNAL OF HEALTHCARE ETHICS \& ADMINISTRATION}

Vol. 5 | No. 1 (Fall/Winter 2019)

Vox, Ford. 2011a. "Wisconsin's Real Doctors and Their Fake Sick Notes for Protesters." The Atlantic. February 21, 2011. https://www.theatlantic.com/national/archive/2011/02/wisconsins-real-doctors-and-their-fakesick-notes-for-protesters/71500/ 